\title{
The Effectiveness of the Financial Intelligence Unit in Maldives in Combating Money Laundering
}

\author{
Ahmed Jaleel ${ }^{1}$, Sharifah Nazatul Faiza Syed Mustapha Nazri ${ }^{2 *}$, \\ Salwa Zolkaflil ${ }^{3}$, Normah Omar ${ }^{3}$ and Nur Aima Shafie ${ }^{3}$ \\ ${ }^{1}$ Maldives Police Service \\ ${ }^{2}$ Faculty of Accountancy, Universiti Teknologi MARA, Malaysia \\ ${ }^{3}$ Accounting Research Institute (HICoE), Universiti Teknologi MARA, Malaysia
}

\begin{abstract}
Money laundering has become a vast global concern, and the rates are growing. Hence, there is a need for a good preventive and monitoring mechanism that monitors suspicious transactions at the source. In Maldives, a Financial Intelligence Unit (FIU) was introduced to gather, analyse, and provide financial intelligence report to law enforcement agencies to proceed with an investigation. The FIU plays a vital role in the Anti-Money Laundering (AML) Regime in successfully combat money laundering activities. Since the AML Regime in Maldives was established in 2014, there is a need to conduct a study to investigate the effectiveness of the FIU in combating money laundering in the Maldives. Based on questionnaires collected from 122 enforcement officers, findings show that reporting mechanisms significantly influence the effectiveness of the FIU. The legal framework and the role of the officer did not significantly influence the effectiveness of FIU. It shows that the competency of LEAs in combating money laundering in the Maldives is still low. Therefore, the government needs to enhance the awareness and competencies of enforcement officers in combating money laundering. Future research may conduct a comparative study to understand further the best reporting mechanism that can help enhance the effectiveness of law enforcement agencies.
\end{abstract}

Keywords: financial intelligence unit, money laundering, reporting mechanism

$\underline{\text { ARTICLE INFO }}$

Article History:

Received: 17 September 2021

Accepted: 12 November 2021

Published: 1 December 2021

*Corresponding author: Sharifah Nazatul Faiza Syed Mustapha Nazri. Email: shari744@uitm.edu.my 


\section{INTRODUCTION}

Money laundering has become a vast global concern, and the rates at which the cases are apprehended and growing are alarming. The consequences associated with money laundering include disruption of economies, interference in the financial sector, reduction in government revenue, and increase in socioeconomic expenses (Beqiri \& Beqiri, 2018). The Maldives has taken money laundering seriously. In securing the country's economy, the Prevention of Money Laundering and Financing of Terrorism Act 2014 (PMLFTA 2014) was introduced in October 12, 2014. One of the initiatives under the Act is establishing the Financial Intelligence Unit (FIU), which is responsible for coordinating and strengthening efforts in combating money laundering and terrorism financing. The FIU Maldives (FIUMv) is the central national agency for receiving, analysing, and disseminating information concerning money laundering activities, terrorism financing activities, and proceeds of crime. Its mandates have been briefed in the Act with its judicial authorities (Maldives Monetary Authority Website, 2020). The FIU has the authority to monitor suspicious transactions happening in the Maldives, in both financial and non-financial institutions stipulated under the Act.

In 2018, Maldives was shocked by a money laundering case involving its former president, Former President Abdulla Yameen, which has made Maldives the centre of attraction with the biggest corruption scandal exceeding U\$90m (Maldives Independent, 2018). In November 2018, the newly appointed president of Maldives, President Ibrahim Mohamed Solih, established the Presidential Commission on Corruption and Asset Recovery, aimed to recuperate the lost assets of the state and investigate cases of corruption embezzlement, and misuse of state funds. One of the major investigations is the money laundering case of former President Yameen, who is currently serving a jail term for money laundering (Moorthy, 2021). It shows that money laundering is an issue of concern in the Maldives since it involves a politically exposed person with power in administrating the country. Hence, there is a need to enhance the effectiveness of all authorities under the anti-money laundering (AML) regime to curb money laundering at the source effectively. 
The issues and concerns of money laundering have been examined. As such, the factors affecting money laundering (Vaithilingam \& Nair, 2007), an overview of AML laws and regulations (Azzam Amal Fadel Tommalieh, 2013; Nguyen, 2014), techniques and cases of money laundering (Muhammaddun Mohamed \& Ahmad, 2012a; Simser, 2012) and the effectiveness of AML regulations (Usman Kemal, 2014; Yeoh, 2014) have been examined and studied. However, limited studies have focused on the role of FIU Maldives in combating money laundering activities. Therefore, this study aimed to identify the factors that influence money laundering investigations, focusing on the influence of reporting mechanisms, legal frameworks, and the role of FIU in money laundering investigation, which will aid to combat money laundering in the Maldives. The findings will assist the authorities in identifying the significant factors that require future improvement in enhancing the role of the FIU, especially in critical matters related to money laundering.

\section{LITERATURE REVIEW}

\section{Situational Crime Prevention Theory}

The Situational Crime Prevention Theory was introduced in the 1970s to focus on crime prevention rather than enforcement by reducing the opportunities for specific types of crime. In the 20th century, this approach became an appropriate technique for the prevention of many crimes such as organized crime (Bullock, Clarke, \& Tilley, 2010), fraud (Smith, Button, Johnston, \& Frimpong, 2010), terrorism (Clarke, 2009) and money laundering (Gilmour, 2016). Von Lampe (2011) defined this Theory as the perspective and pragmatic approach to preventing crime.

Situational crime prevention focuses on altering potential criminal behaviour by creating an environment and situation, also known as an intervention, that makes it difficult for criminals to commit a crime. In recent years, situation crime prevention has been steadily modified to meet the government's requirements, lawmakers and law enforcement authorities, which is proven to be more successful (Bullock et al., 2010; Von Lampe, 2011). Having a comprehensive legal framework to prevent specific crime is one of the interventions used by many countries in preventing 
crime, especially money laundering. In line with the Theory, Maldives has introduced a comprehensive money laundering legal framework to assist in the effort of combating money laundering activities happening in the Maldives.

Therefore, this study refers to the Situational Prevention Crime Theory to understand the effectiveness of the reporting mechanism within the FIU functions in combating money laundering in the Maldives. There are three factors that can be referred to in determining the effectiveness of the AML Regime in combating money laundering, namely legal framework (Dhillon, Ahmad, Rahman, \& Yih Miin, 2013), reporting mechanism (Mohammed and AlRashdan; Ross \& Hannan, 2007), and role of FIU in fighting money laundering crime (Acharya, 2015).

\section{Money Laundering}

Money laundering refers to the process of converting illicit gained income, such as proceeds from corruption, fraud, extortion, drug and human trafficking, and many other criminal activities, to a legitimate source of income (Gottschalk, 2010; Mahammaddun Mohamed \& Ahmed, 2012; Madinger; 2011; Mugarura, 2016; Thanasegaran \& Shanmigam, 2008; UN Convention, 2000). The criminals aim to hide the original source, twist information regarding the ownership of the properties, and end up using the assets obtained through illegal means (Pereira, Pedro Gomes, Selvan Lehmann, \& Anja Roth, 2012). There are three stages involved in this process to accelerate money laundering, which are placement, layering, and integration (Muhammaddun Mohamed \& Ahmad, 2012; Shanmugam, Nair, \& Suganthi, 2003).

In the placement stage, illegally obtained money is dissociated from both the crime and the criminals. It is frequently done by depositing in financial institutions in smaller amounts of cash and may involve different banking accounts to avoid being detected by a regulated system (Moamil, 2014). The second stage of the process, known as layering, refers to physical dispersing or smurfing the funds into various financial institutions internationally to conceal its trail further from its origin (Rachagan \& Kasipillai, 2013). In the layering stage, the launderer wants to disguise the audit route and provide anonymity, making it difficult for the law 
enforcement agencies (LEAs) to trace back the source of funds (Omar, Johari, \& Arshad, 2014).

The final stage of the money laundering process is the integration stage. In this stage, the launderer is reconciled with laundered funds which are enclosed in legitimacy, making it legal. As mentioned earlier, money laundering generates a perpetual circle of criminality; the laundered money can subsequently lead to funding for further criminal activities (Keesoony, 2016). Shanmugam et al. (2003) mentioned that money laundering involves a process by which the proceeds of crime are brought into an organisation and legitimate financial system. Hence, this highlights the importance of FIU's role to monitor any suspicious transactions in the financial system as an initiative in combating money laundering activities.

\section{Anti-Money Laundering Legal Framework for the Maldives}

In recent decades, money laundering has significantly intensified worldwide. Countries are encouraged to amend their anti-money laundering laws and regulations according to the international requirements to meet their foreign counterparts (Simwayi \& Haseed, 2011).

Money laundering was first regulated in the Maldives when President Yameen ratified the Prevention of Money Laundering and Financing of Terrorism Act 2014 (PMLFTA 2014) in April 2014. The Act was legislated with pressure from international organizations to participate in the global fight against these corrosive issues following recommendations to eliminate money laundering and terrorism financing. The provisions of the Act contain nineteen chapters in seven parts. The Act defined measures and actions required for the detection and prevention of money laundering and terrorism financing, as well as the organization and controlling of the applications. Furthermore, the Act also included legal consequences and powers given to law enforcement authorities to carry out necessary measurements to fight against money laundering and terrorism financing.

The legal framework can also be described as the framework of laws and regulations put in place by the legislative authorities to achieve an order either in a sector or the entire legal system of a country. The PMLFTA2014 consists of seven parts. Part One covers chapter one and two focuses on the 
introduction on money laundering. Part two has four chapters, from chapter three to chapter six, that covers on the prevention of money laundering and financing of terrorism. Part three of the Act focuses on detection provisions. This includes from chapter seven until chapter eleven. Part four of the Act includes only chapter thirteen, which is regarding the investigation powers, including the investigation techniques and operational procedures. Part six of the Act is regarding international cooperation and affiliation with other foreign counterparts. In contrast, Part seven is miscellaneous, where it focuses on general provisions of the Act, such as regulations required and definitions. The content of the PMLFTA 2014 is summarized in Table 1.

Table 1: Summary of Prevention of Money Laundering and Financing of Terrorism Act 2014 (PMLFTA 2014)

\begin{tabular}{|c|c|c|}
\hline Part & Chapter & Item \\
\hline \multirow{2}{*}{$\begin{array}{l}\text { One: } \\
\text { Preliminary }\end{array}$} & One & Introduction and Objectives \\
\hline & & Dictionary of Concepts \\
\hline \multirow{4}{*}{$\begin{array}{l}\text { Two: } \\
\text { Prevention of Money } \\
\text { Laundering and Financing of } \\
\text { Terrorism }\end{array}$} & Three & Preventive Measures \\
\hline & Four & $\begin{array}{l}\text { Non-Profit Organizations, Money or Value } \\
\text { Transfer Service Providers, and Designated } \\
\text { Non-Financial Business and Profession }\end{array}$ \\
\hline & Five & Other Preventive Measures \\
\hline & Six & $\begin{array}{l}\text { Disclosure of Information of Financial } \\
\text { Transactions }\end{array}$ \\
\hline \multirow{5}{*}{$\begin{array}{l}\text { Three: } \\
\text { Detection of Money } \\
\text { Laundering and Financing of } \\
\text { Terrorism }\end{array}$} & Seven & Financial Intelligence Unit \\
\hline & Eight & Reporting of Suspicious Transactions \\
\hline & Nine & Exemption from Liability \\
\hline & Ten & Responsibilities of Supervisory Authorities \\
\hline & Eleven & $\begin{array}{l}\text { Exemption from Banking Secrecy and } \\
\text { Professional Privilege }\end{array}$ \\
\hline $\begin{array}{l}\text { Four: } \\
\text { Part on Investigation }\end{array}$ & Twelve & Investigation \\
\hline \multirow{3}{*}{$\begin{array}{l}\text { Five: } \\
\text { Penalties and Provisional } \\
\text { Measures }\end{array}$} & Thirteen & $\begin{array}{l}\text { Provisional Measures and Freezing and } \\
\text { Seizing of Funds and Properties }\end{array}$ \\
\hline & Fourteen & Offences and Penalties \\
\hline & Fifteen & Confiscation by the State \\
\hline \multirow{3}{*}{$\begin{array}{l}\text { Six: } \\
\text { Establishing and Maintaining } \\
\text { International Cooperation }\end{array}$} & Sixteen & General Provisions \\
\hline & Seventeen & $\begin{array}{l}\text { Security Measures Concerning Financing of } \\
\text { Terrorism }\end{array}$ \\
\hline & Eighteen & Extradition and Mutual Legal Assistance \\
\hline $\begin{array}{l}\text { Seven: } \\
\text { Miscellaneous }\end{array}$ & Nineteen & General Provisions \\
\hline
\end{tabular}


The legal framework is the backbone and guideline for investigators and prosecutors to reach a favourable conclusion. Currently, the FIUMv is obligated to alert law enforcement agencies of potential money laundering activity via the suspicious reports collected. The enforcement agencies are tasked to evaluate if the funds mentioned in the STR's of FIUMv are, in fact, funds obtained through methods involving criminal activities. According to the current investigative structure, law enforcement agencies work closely in collaboration with the Prosecutor. Therefore, establishing legal grounds and potential charges based on the findings of investigations in real-time, are relatively quick. However, virtually none of such allegations are backed with enough evidence from investigations, leading to a low rate of prosecution. In addition, the current system does not facilitate the relevant authorities to seize alleged funds/properties or proceeds of the crime unless and until it has been established at court that items being discussed are indeed proceeds of crime.

In determining the effectiveness of the AML Regime in combating money laundering, it is crucial to not only look for transactions but to understand the legal implications or mechanisms in place. These legal provisions or processes are vital for law enforcement agencies (Dhillon, Ahmad, Rahman, \& Yih Miin, 2013). The prosecution can prove that there is an occurrence of money laundering; if there is sufficient evidence that indicates engagement or involvement in a specific kind of illegal activity or that there is evidence that property was handled in a manner that would have caused an irresistible interference which could only be derived from a crime. Therefore, this research tested the first hypothesis as the relationship between the effectiveness of the legal frame and the effectiveness in combating money laundering.

$\mathbf{H}_{\mathbf{1}}$ : There is a significant relationship between the effectiveness of the legal framework and combating money laundering.

\section{Reporting Mechanisms in Anti-Money Laundering Regime}

The Suspicious Transaction Report (STR) or Suspicious Activity Report (SAR) is an essential indicator to measure Anti-Money Laundering. It can be measured through the quality and quantity of such reports in order to measure the effectiveness of the money laundering investigation (Viritha, 
Mariappan, \& Haq, 2015). These are essential components of AML measures as they become a critical and important piece of evidence in treating a case on the threat level and categorising it as suspicious activity. Customer Identification Procedures, such as Customer Due Diligence (CDD) and Know Your Customer (KYC) requirements, plays a vital role in the money laundering prevention and detection (Basel Committee, 1988) to ensure that the banking system is not used as a pipeline to wash dirty money and make it legit. This procedure will also assist in implementing reporting mechanisms with law enforcement agencies. However, Rahman (2013) elaborated that the STR regime appears to be under-utilized by several law enforcement agencies. This is due to a lack of resources, collaboration, and IT infrastructure.

Money laundering indeed involves financing institutions (Shanmugam, Nair, \& Suganthi, 2003). Therefore, the FIU as the supervisory authority must ensure compliance by financing institutions with the laws and regulations accordingly. These measurements must be aligned with the obligations of the AML standards. Some of the critical components that need to be in place include; collecting relevant information of customers, obliteration of suspicious funds, and ensuring that these funds are not used for criminal purposes. Therefore, establishing a well-functioning reporting mechanism is vital in supporting FIU operations in combating money laundering. Hence, the role of reporting entities and established reporting mechanisms are an influencing factor to mitigate money laundering.

Mohammed and AlRashdan (2012) stated that the success of any reporting mechanism depends on the authorities' ability to properly supervise them and power vested obligated in wherever it needs to be implemented. One of the most fundamental elements of the AML measures include the Suspicious Transactions Reporting (STR) regime. This refers to a critical piece of information that could provide evidence of a money laundering activity or terrorism financing scheme (Menz, 2019; Ross \& Hannan, 2007). It is imperative that STR is obliged to provide all the details regarding a suspicious case, irrespective of the amount, type of the crime, and threat level of the criminal activity. And this should have no dependence on the financial modality or system employed by the reporting entity (Chaikin, 2009). 
Thus, the quality of the reporting system and its efficiency will be beneficial for the investigation of money laundering. Therefore, this study intends to see if there is a relationship between effective reporting mechanisms and money laundering.

$\mathbf{H}_{2}$ : There is a significant relationship between effective reporting mechanisms and money laundering in the Maldives.

\section{The Role of FIUMv in Combating Money Laundering}

The FIU Maldives (FIUMv) was established under the Maldives Law No. 10/2014, Prevention of Money Laundering and Financing of Terrorism Act (PMLFTA, 2014) within the Maldives Monetary Authority (MMA). Its core functions include receiving, assessing, and disseminating intelligence information regarding money laundering activities, financing terrorism activities, and other financial crimes (PMLFTA 2014). However, the Act has not been given investigative power to FIU Maldives for the offence of money laundering crime or any other financial crimes but to report such crimes to law enforcement agencies.

The FIUMv has been working with the reporting institutes, regulators, and LEAs to mitigate money laundering and fight its predicate offences (FIU, 2018) as it is mandated in the Act. The initiatives include (i) international cooperation and affiliations, (ii) ensuring that STR reported from institutions are appropriately analysed, and (iii) financial intelligence is disseminated to the relevant law enforcement agencies and regulatory authorities.

Therefore, FIU is one of the key institutes that is established in fighting money laundering crime (Acharya, 2015). One of the core functions of FIU involves the collection and dissemination of reports to the concerned authorities. The information provided would be valuable to investigate fraud and money laundering investigations. Hence, the third hypothesis of this study was that there is an association between the effective role of FIU and effectiveness in money laundering investigation.

$\mathbf{H}_{3}$ : There is a significant relationship between the effective role of FIU and combating money laundering. 
Hence, the research framework for this study is illustrated in Figure 1.

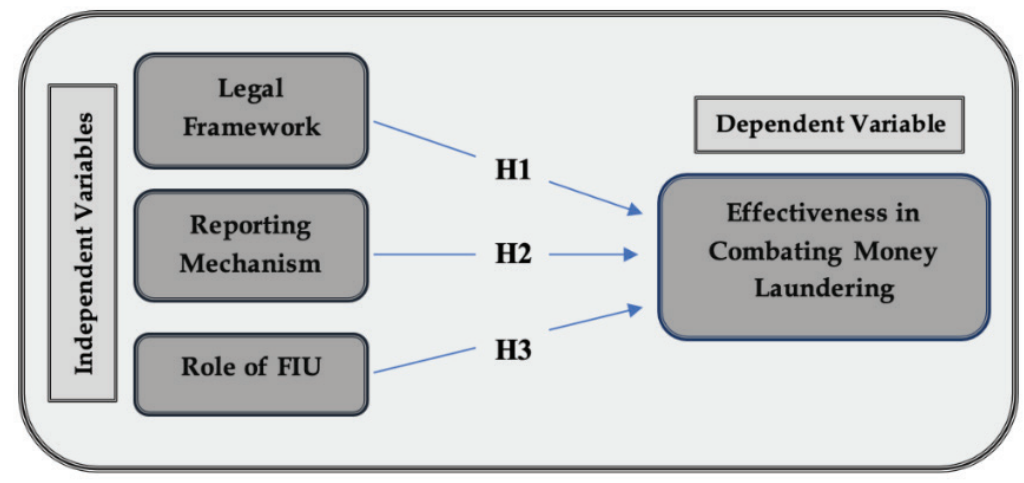

Figure 1: Research Framework

\section{RESEARCH METHODOLOGY}

This study was a quantitative study using a structured questionnaire to get responses from the respondents, according to Creswell (1994) and Leedy and Ormrod (2001). Simple non-random sampling was used as it was convenient, focusing on money laundering investigating officers who handle money laundering cases in the Maldives. The questionnaires were distributed to 175 officers in six (6) different law enforcement agencies through a google form after obtaining informed consent. Out of 175 distributed questionnaires, there were 122 responses received from the respondents, which is equal to a $70 \%$ response rate. The response rate is in line with the minimum sample size requirement mentioned by Green (1991). In conducting this study, anonymity and confidentiality were strictly maintained for all the data collected. The participants were explained of the aims of the study, and their consent was obtained before filling the questionnaire.

The questionnaire had two components. The first component was to collect socio-demographic information such as age, gender, educational qualifications, and professional. The second component was to use an interval scale to get responses to a set of items related to the key concepts of the study. All the 26 items were based on a 5-point Likert scale, with 1 being strongly agree and 5 is strongly disagree. Respondents were required to select one option among the 5 scales. 
Table 2 shows the items used in the questionnaire to measure the independent variables, namely legal framework (LF), reporting mechanisms (RM), and role of FIU (FIU). The items were measured using a 5-point Likert scale.

Table 2: Operational Measurements of Independent Variables

\begin{tabular}{l} 
Construct \\
\hline Legal Framework \\
(LF) \\
Definition: \\
Effectiveness of \\
legal requirements \\
established in fighting \\
and preventing ML and \\
the effectiveness of \\
current legal framework \\
practicing in the \\
Maldives to combat ML.
\end{tabular}

Items

\section{Statements}

LF1 Money laundering issues are sufficiently addressed in the current implemented legal frameworks of Maldives.

LF2 PMLTFA 2014 of Maldives sufficiently addresses the issues of ML problem in the Maldives.

LF3 PMLTFA 2014 has enacted FIU's legal powers and authorities to function combat $\mathrm{ML}$ issues in Maldives.

LF4 Maldives needs to introduce procedures to freeze and acquire assets that have been obtained through alleged money laundering schemes.

LF5 Introducing and implementing the whistleblowing act in the Maldives will increase the reporting of suspicious transactions reporting entities.

LF6 FIUMv needs legal powers to investigate alleged cases of $\mathrm{ML}$ and enforce legal requirements.

Reporting Mechanism (RM)

\section{Definition:}

Procedural and obligatory systems for effective reporting procedures for combating ML through reflags and STRs.

Effectiveness of FIUMv in supervising adherence to AML regulations among financial institutions in the Maldives

RM2 Reporting mechanisms of Maldives financial institutions in accordance with international requirements and the local AML regime.

RM3 Exchange of information of STRs and CTRs with LEAs and FIU for effective
Reference

Samwayi

\& Haseed

(2011)

Kutubi

(2011)
Viritha et al. (2015) combating of money laundering.

RM4 Reporting of alarming KYC red flags directly to LEAs for quick response for an effective money laundering investigation.

RM5 The reporting institutes in the Maldives have established procedural mechanisms to report STRs to the authorities as per local and international laws and regulations. 


\begin{tabular}{|c|c|c|c|}
\hline Construct & Items & Statements & Reference \\
\hline $\begin{array}{l}\text { Role of FIU } \\
\text { (FIU) }\end{array}$ & RFIU1 & $\begin{array}{l}\text { FIU has the ability to prevent and combat } \\
\text { money laundering through its mandated } \\
\text { operational functions. }\end{array}$ & $\begin{array}{l}\text { Mniwas } \\
(2019)\end{array}$ \\
\hline \multirow{6}{*}{$\begin{array}{l}\text { Definition: } \\
\text { Effectiveness in } \\
\text { operational functions } \\
\text { and obligatory } \\
\text { mandates of FIU in } \\
\text { combating money } \\
\text { laundering by providing } \\
\text { necessary information } \\
\text { to LEAs. }\end{array}$} & RFIU2 & $\begin{array}{l}\text { FIUMv has the authority and capacity to } \\
\text { carry out its functions freely, including the } \\
\text { autonomous decision to analyse, request } \\
\text { and /or disseminate specific information. }\end{array}$ & $\begin{array}{l}\text { Aziz Kanak } \\
(2016)\end{array}$ \\
\hline & RFIU3 & $\begin{array}{l}\text { FIUMv provides training programs to } \\
\text { fellow government agencies to educate } \\
\text { on combating } M L \text { and terrorism financing. }\end{array}$ & \\
\hline & RFIU4 & $\begin{array}{l}\text { Authorities and legal powers of FIUMv in } \\
\text { the collection, receiving and sharing of } \\
\text { information. }\end{array}$ & \\
\hline & RFIU5 & $\begin{array}{l}\text { FIUMv is able to make arrangements } \\
\text { or engage independently with other } \\
\text { domestic competent authorities or } \\
\text { foreign counterparts for the exchange of } \\
\text { information }\end{array}$ & \\
\hline & RFIU6 & $\begin{array}{l}\text { FIUMv is able to protect the data it receives } \\
\text { as well as the financial intelligence and } \\
\text { other information it generates. }\end{array}$ & \\
\hline & RFIU7 & $\begin{array}{l}\text { FIUMv independence from influence and } \\
\text { interference from different stakeholders. }\end{array}$ & \\
\hline
\end{tabular}

Meanwhile, the dependent variable of this study was the effectiveness in combating money laundering (ECML), as summarized in Table 3. The effectiveness in combating money laundering was defined as a measurement through the prosecution of money laundering and confiscation of assets which are derived from the process of money laundering and its predicated offences to establish a safe and sound financial system to protect from any misuse of it for illegal activities such as money laundering. (Aurasu \& Rahman, 2016). 
Table 3: Operational Measurements of Dependent Variable

\begin{tabular}{|c|c|c|c|}
\hline Construct & Items & Statements & Reference \\
\hline \multirow{8}{*}{$\begin{array}{l}\text { Effectiveness in } \\
\text { Combating Money } \\
\text { Laundering } \\
\text { Definition: } \\
\text { Procedures and } \\
\text { frameworks are } \\
\text { currently practicing to } \\
\text { prevent and combating } \\
\text { money laundering } \\
\text { through investigation } \\
\text { and prosecution. }\end{array}$} & ECML1 & $\begin{array}{l}\text { FIUMv's role in combating ML by enforcing } \\
\text { its regulated functions. }\end{array}$ & \multirow{2}{*}{$\begin{array}{l}\text { Mulenda } \\
\text { \& Muraji } \\
(2014)\end{array}$} \\
\hline & ECML2 & $\begin{array}{l}\text { Maldives legal frameworks and legislations } \\
\text { are sufficient for LEAs in combating ML. }\end{array}$ & \\
\hline & ECML3 & $\begin{array}{l}\text { Effectiveness and efficient to confiscate } \\
\text { assets rather than prosecute ML cases in } \\
\text { the Maldives. }\end{array}$ & \multirow[t]{6}{*}{$\begin{array}{l}\text { (Aurasu \& } \\
\text { Rahman, } \\
\text { 2016) }\end{array}$} \\
\hline & ECML4 & $\begin{array}{l}\text { Training and career development of } \\
\text { investigation officer / AML compliance } \\
\text { officers. }\end{array}$ & \\
\hline & ECML5 & Reinforcing enforcement of regulations. & \\
\hline & ECML6 & $\begin{array}{l}\text { Adaptation of International best practices } \\
\text { and recommendations }\end{array}$ & \\
\hline & ECML7 & $\begin{array}{l}\text { Developing and implementing necessary } \\
\text { tools and technologies }\end{array}$ & \\
\hline & ECML8 & Increasing the awareness about AML & \\
\hline
\end{tabular}

The data were compiled and collated for analysis. IBM SPSS software was used to conduct descriptive and regression analysis to have a better understanding of the research framework. Regression analysis was undertaken to find the influence of the legal framework, reporting mechanisms, and the role of FIU to predict the effectiveness of money laundering investigation, referring to the formula summarised in Figure 2.

$$
\mathrm{ECML}=\alpha+\beta_{1} \mathrm{LF}+\beta_{2} \mathrm{RM}+\beta_{3} \mathrm{RFIU}+\varepsilon
$$

Where:

$\mathrm{ECML}=$ Effectiveness in Combating Money Laundering (dependent variable)

$\alpha \quad=$ Constant coefficient (Intercept)

$\beta_{1}-\beta_{3}=$ Coefficient of variable (Explanatory)

$\left.\begin{array}{ll}\text { LF } & =\text { Legal Framework } \\ \text { RM } & =\text { Reporting Mechanism } \\ \text { RFIU } & =\text { Role of FIU }\end{array}\right\} \quad$ (Independent variables)

RFIU $=$ Role of FIU

$\varepsilon \quad=$ Residual component of model (Error term)

Figure 2: Regression Model of the Study 


\section{FINDINGS, ANALYSIS AND DISCUSSION}

\section{Demographical Information}

The characteristics of the respondents is illustrated in Table 4 for each category, including gender, age, and educational background.

Table 4: Demographic Information of Respondents

\begin{tabular}{llcc}
\hline & Descriptive & \multicolumn{2}{c}{ Total (N=122) } \\
& Male & Frequency & Percentage \\
\hline \multirow{2}{*}{ Gender } & Female & 74 & 61 \\
& & 48 & 39 \\
& 18 years to 24 years & 29 & 24 \\
Age & 25 years to 35 years & 67 & 55 \\
& 36 years to 45 years & 20 & 16 \\
& 46 years and above & 6 & 5 \\
Educational & Higher Education & 8 & 7 \\
Qualification & Diploma & 23 & 19 \\
& Bachelor's Degree & 52 & 43 \\
& Master's Degree & 39 & 32 \\
\hline
\end{tabular}

As shown 48 of the respondents were female, and 74 of respondents, male. Most of these respondents were from the age group of 25 years o 35 years, which was 67 respondents; followed by 29 respondents, from age category 18 years to 24 years. 20 respondents were from age group 36 years to 45 years above 46 years, and the lowest respondents consist of those above 46 years, six (6) respondents.

As for their educational qualification, the majority of respondents (52) held a degree-level education. Out of 122 respondents, 39 held a master's degree, while 23 had diploma level qualifications. The rest eight (8) respondents at least had completed their higher education qualification. The respondents comprised of officers directly involved with money laundering investigation and prosecution in the Maldives. They were from the Maldives' law enforcement agencies. With different gender, various age 
groups, educational backgrounds and positions, the findings will be able to provide evidence that will be fruitful to the money laundering investigation and prosecution in the Maldives.

\section{Descriptive Statistical Analysis of Questionnaire Items}

The study aimed to examine the influence of combating money laundering in the Maldives, focusing on three factors: legal framework, reporting mechanisms, and the role of FIU. The coefficient variance was used to compare between two or more magnitudes of variation that are meaningful, even if they have different means or different scales of measurement (Banik, Kibria, \& Sharma, 2012). The descriptive statistics for the three factors are displayed in Table 4.

The results for the framework factor gave an average mean score of 3.33 with a standard deviation of 0.90 . This result indicated that most of the respondents were neither agreed nor disagreed, but consistent with uncertainty regarding the statements of the legal framework construct. The mean score indicated that the majority of the respondents and the individual perception score did not differ much from each other.

Under the reporting mechanism, the results gave an average mean score of 3.06 with an overall standard deviation of 0.99 . This result indicated that most of the respondents agreed with the statements provided in the reporting mechanism construct. Based on a single statement, the majority of the respondents agreed that the supervision of adherence to AML regulations among financial institutions by the FIU had effectively maintained a mean score of 2.68 .

As for the role of the FIU, the results gave an average mean score of 3.21 with a standard deviation of 0.83 . This result projected that the majority of the respondents were uncertain with the statements measured in the role of the FIU. As for the dependent variable, effectiveness in combating money laundering in the Maldives gave an average mean score of 2.31 with a standard deviation of 0.90 . 
Table 5: Mean Score and Standard Deviation for Legal Framework, Reporting Mechanism, and Role of FIU.

\begin{tabular}{ll}
\hline Items & \multicolumn{1}{c}{ Statements } \\
\hline LF1 & $\begin{array}{l}\text { PMLTFA 2014 has enacted FIU's legal powers and } \\
\text { authorities to function combat ML issues in Maldives. }\end{array}$ \\
LF2 & $\begin{array}{l}\text { Maldives needs to introduce procedures to freeze and } \\
\text { acquire assets that has been obtained through alleged } \\
\text { ML schemes. }\end{array}$ \\
LF3 & $\begin{array}{l}\text { Introducing and implementing whistleblowing act in } \\
\text { the Maldives will increase the reporting of suspicious } \\
\text { transactions from non-financial and financial institutions }\end{array}$ \\
RM1 & $\begin{array}{l}\text { The supervision of adherence to AML regulations } \\
\text { among financial institutions by FIU has been effectively } \\
\text { maintained. }\end{array}$
\end{tabular}

\section{Mean}

3.40

3.21

2.68

RM2 The Maldives financial institutions have established international requirements for anti-money laundering standards and procedures in compliance with AML.

RM3 The Maldives financial institutions have well established mechanisms for the exchange of information of STRs and CTRs with LEAs and FIU.

RFIU1 FIU has the ability to prevent and combat money laundering through an effective money laundering investigation.

RFIU2 FIUMv has the authority and capacity to carry out its functions freely, including the autonomous decision to analyse, request and /or disseminate specific information.

RFIU3 FIUMv provides training programs to fellow government agencies to educate in combating ML.

RFIU4 FIUMv is authorised to request additional information on $M L$ and suspicious transactions from financial and nonfinancial institutions either directly or through another authority.

RFIU5 FIUMv is able to make arrangements or engage independently with other domestic competent authorities or foreign counterparts for the exchange of information. 


\begin{tabular}{|c|c|c|c|}
\hline Items & Statements & Mean & $\begin{array}{l}\text { Standard } \\
\text { Deviation }\end{array}$ \\
\hline RFIU6 & $\begin{array}{l}\text { FIUMv is able to protect the data it receives as well as the } \\
\text { financial intelligence and other information it generates. }\end{array}$ & 3.13 & 1.29 \\
\hline RFIU7 & $\begin{array}{l}\text { FIUMv should be able to obtain and deploy the resources } \\
\text { needed to carry out its functions on an individual or } \\
\text { routine basis, free from any undue political, government, } \\
\text { or industrial influence or interference, which might } \\
\text { compromise its operations. }\end{array}$ & 2.85 & 1.35 \\
\hline ECML1 & $\begin{array}{l}\text { The Maldives FIU plays a vital role in combating ML by } \\
\text { enforcing its regulated functions. }\end{array}$ & 2.82 & 1.35 \\
\hline ECML2 & $\begin{array}{l}\text { Training and career development of investigation officer } \\
\text { / AML compliance officers. }\end{array}$ & 2.58 & 1.19 \\
\hline ECML3 & Reinforcing enforcement of regulations. & 2.09 & 1.18 \\
\hline ECML4 & $\begin{array}{l}\text { Adaptation of International best practices and } \\
\text { recommendations }\end{array}$ & 2.14 & 1.19 \\
\hline ECML5 & $\begin{array}{l}\text { Developing and implementing necessary tools and } \\
\text { technologies }\end{array}$ & 2.13 & 1.21 \\
\hline ECML6 & Increasing the awareness about AML & 2.11 & 1.23 \\
\hline
\end{tabular}

\section{Reliability Test}

This study adapted questionnaire items from the existing literature based on the Maldives environment. The questionnaire consisted of 19 items with four (4) constructs that best fit the study. These 19 items were related to four (4) variables which were legal framework (3 statements), reporting mechanism ( 3 statements), the role of FIU ( 7 statements), and effectiveness in combating money laundering (6 statements).

The reliability test was carried out to determine the reliability of the statements. The Cronbach alpha was used to measure the reliability of the constructs used in the study. Table 6 below demonstrates the Cronbach alpha coefficient for the items used in the study; that included four variables with 19 statements. 
Table 6: Reliability Statistics for the variables

\begin{tabular}{lllcc}
\multicolumn{1}{c}{ Variables } & & \multicolumn{1}{c}{ Constructs } & Items & Cronbach's Alpha \\
\hline Independent & IV1 & Legal Framework & 3 & 0.765 \\
Variables & IV2 & Reporting Mechanism & 3 & 0.708 \\
\hline \multirow{2}{*}{ Dependent Variable } & IV3 & Role of FIU & 7 & 0.799 \\
& DV & Effectiveness in Combating ML & 6 & 0.826 \\
\hline
\end{tabular}

Therefore, items used in the measurements were considered reliable based on the 0.70 recommendation of Whitley and Robinson $(2010 ; 2002)$. The general rule is that reliability greater than 0.80 is considered as high (Graziano \& Raulin, 2006). The results showed that the items used in this study can be regarded as highly reliable and can be used to measure the constructs.

\section{Pearson Correlation Analysis}

Table 7 presents the statistics for Pearson correlation coefficient analysis between the variables.

Table 7: Pearson Correlation Coefficient between variables

\begin{tabular}{lcccc} 
& $\begin{array}{c}\text { Legal } \\
\text { Framework }\end{array}$ & $\begin{array}{c}\text { Reporting } \\
\text { Mechanisms }\end{array}$ & $\begin{array}{c}\text { Role } \\
\text { of FIU }\end{array}$ & $\begin{array}{c}\text { Effectiveness } \\
\text { in Combating } \\
\text { ML }\end{array}$ \\
\hline Legal Framework & 1 & & & \\
Reporting Mechanisms & 0.613 & 1 & & \\
Role of FIU & 0.663 & 0.672 & 1 & 1 \\
Effectiveness in Combating ML & -0.016 & 0.103 & -0.052 & 1 \\
\hline
\end{tabular}

The results showed - a moderate correlation between legal framework and reporting mechanism with an $r$ value of 0.663 and a $p$-value of 0.000 . This presented a positive statistically significant correlation between these two variables. Likewise, the legal framework and role of FIU also present a moderate positive correlation between these two variables, which gave an $\mathrm{r}$ value of 0.672 and a p-value of 0.000 . Therefore, these two variables had a moderate positive statistically significant correlation. In addition, reporting mechanism and role of FIU also presented a moderate positive correlation. These two variables provided a $r$ value of 0.672 with a significance level p-value of 0.000 . The correlation between the independent variables; legal framework, reporting mechanisms, and role of FIU gave r values of -0.016 , 
0.103 , and -0.052 towards the dependent variable, which was effectiveness in combating money laundering.

This indicated that all these variables had no correlation towards effectiveness in combating money laundering due to $r$-value falls between -0.2 to 0.2 range. When there is a $p$-value less than 0.05 , it indicated that it is statistically significant. The p-values of all independent variable legal framework, reporting mechanism, and role of FIU gave p-value $<0.05$ towards effectiveness in combating money laundering as p-values 0.865 , 0.257 , and 0.569 , respectively. Therefore, it can be concluded that none of the independent variables provided a significant correlation at the 0.05 level between the dependent variable. Hence collinearity was not an issue for this study.

\section{Regression Analysis}

The regression model specifies the relationship of the dependent variable (Y), in this study, that is, effectiveness in combating money laundering (ECML) to a function combination of independent variables $(\mathrm{X})$, which are legal framework (LM), reporting mechanisms (RM) and role of FIU (RFIU).

Table 8: Regression Analysis (Hypothesis Testing)

\begin{tabular}{lccccc} 
& Beta & $\begin{array}{c}\text { Standard } \\
\text { Error }\end{array}$ & t-value & p-value & VIF \\
\hline (Constant) & 2.148 & 0.367 & 5.857 & 0.000 & \\
Legal Framework (LF) & -0.052 & 0.144 & -0.365 & 0.716 & 1.963 \\
Reporting Mechanisms (RM) & 0.300 & 0.124 & 2.083 & $0.039^{*}$ & 2.008 \\
Role of FIU (FIU) & -0.205 & 0.138 & -1.487 & 0.140 & 2.235 \\
Adjusted R Square & & & 0.014 & & \\
F Square & & & 1.583 & & \\
\hline
\end{tabular}

* Significant at the level of 0.05

The results as shown in Error! Reference source not found. above, shows the adjusted $R$-Square presented the relationship of 0.014 , which proposes $1.4 \%$ of the variance for the effectiveness in combating money laundering in the Maldives. The $R$-Square $1.4 \%$ explained the coefficient of determination by three variables used in the study. The remaining 0.986 
(98.6\%) of the variance for the effectiveness in combating money laundering justified the other variables or concepts that were not tested in this study model. Therefore, this model explained that there was a very weak variability of the response data and around its mean. To determine the relationship between independent and dependent variables, regression analysis of variance (coefficient) was done, the results of which, are presented in Table 8. Based on the coefficients output, collinearity statistics obtained a VIF value of 1.963 for the legal framework. Reporting mechanism and role of FIU presented a VIF value of 2.008 and 2.235, respectively. This indicated that the VIF values of independent variables obtained were between 1 to 5 (Ringle, Wende \& Becker, 2015). Therefore, it can be concluded that there were no multicollinearity issues.

According to the results, there was a negative relationship between legal framework and effectiveness in combating money laundering. The p-value was more than $0.05\left[t_{(118)}=-0.365, p=0.716\right]$, hence was not statistically significant, and hypothesis 1 was rejected. Meanwhile, reporting mechanisms showed a positive relationship with a t-value equal to 2.083 and a p-value equal to 0.039 , hence statistically significant at the $5 \%$ level, and hypothesis 2 was accepted. The results showed that reporting mechanisms had a significant and positive relationship with the effectiveness in combating money laundering. In other words, effective reporting mechanisms will eventually improve the effectiveness of combating money laundering in the Maldives. On the other hand, Table 8 also shows that the role of FIU did not influence the effectiveness in combating money laundering since the $\mathrm{t}$-value is less than 1.245 and a $\mathrm{p}$-value is more than 0.05 . Hence Hypothesis 3 was rejected.

The regression analysis presented that only reporting mechanisms were reliable for predicting the dependent variable with a statistically significant relationship. Table 9 presents the summary of hypotheses developed to achieve the objectives of the study. The study findings enabled to extrapolate further on study objectives, which in turn helped to interpret better and understand the findings of the study to reach an inference. 
Table 9: Summary of Hypotheses Tested

\begin{tabular}{llcc}
\hline \multicolumn{1}{c}{ Hypotheses } & $p$-value & Results \\
\hline H1 & $\begin{array}{l}\text { There is an influence between legal framework effectiveness } \\
\text { and the effectiveness in combating money laundering. }\end{array}$ & 0.716 & Rejected \\
H2 $\quad \begin{array}{l}\text { There is an influence between effective reporting mechanisms } \\
\text { and the effectiveness in combating money laundering in the }\end{array}$ & 0.039 & Accepted \\
$\begin{array}{l}\text { Maldives. } \\
\text { H3 } \quad \begin{array}{l}\text { There is an association between the effective role of FIU and } \\
\text { the effectiveness in combating money laundering. }\end{array}\end{array}$ & 0.140 & Rejected \\
\hline
\end{tabular}

Findings showed that Hypothesis 1 and Hypothesis 3 were rejected while Hypothesis 2 was accepted. This study found that there is a lack of legal framework and effective role of FIU in combating money laundering activities in Maldives (hypothesis 1). This is in line with studies found by Dhillon et al. (2013) and Naheem (2018), which explained the weak legal framework in Malaysia and Saudi Arabia respectively, has failed to enforce legal measures in their local settings effectively. This result could be due lack of understanding among the respondents since money laundering was newly introduced in their country. Therefore, there is a need to create a better legal understanding among the respondents to enhance their understanding of money laundering.

As for Hypothesis 2, the result was aligned with Rahman (2013) and Jayasekara (2018), who found that establishing guidance and supportive feedback and reporting mechanism has a significant effect on the effectiveness level that AML measures. This shows that there might be some provisions for further improvement by addressing the challenges and gaps in the existing reporting system and mechanisms. At the same time, it is also important to further study and better understand the specific details in the reporting systems. This will enable to strengthen reporting of STRs with FIU to improve the financial intelligence supplied to LEAs.

The results of this study indicated no significant relationship between the effective role of FIU's and its ability to effectively combat money laundering. Simwayi and Haseed (2011) found out that the FIU in Zimbabwe was less effective in combating money laundering due to the process of establishments and operational functionality. It indicated that the FIU in Zimbabwe had less influence on the effectiveness of the country's fight against money laundering. Mohammad Al-Rashdan (Mohammad \& 
AlRashdan, 2012) explains the necessity for establishing quality protocols within the FIUs.

However, findings showed that the FIU was not effective in combating money laundering. This could be due to the lack of investigation powers and other necessary legal powers enacted in the Act. Most of the respondents agreed that the FIU needs its legal powers to enhance the functionality in detecting and preventing money laundering. This will enable them to strengthen their initiatives to fight against money laundering in the Maldives. Klimova (2016) emphasized that FIU and reporting entities should emphasis on the need to enhance the exchange of financial information within the legal system. Hence, this will eliminate the causes of delays and minimize the obstructs for the prosecution of money laundering cases.

\section{CONCLUSION}

This study was among the first of its kind in understanding the function of the FIU in combating money laundering activities in the Maldives. Money laundering is relatively new in the Maldives since the first money laundering case was convicted in 2019. Findings showed that the reporting mechanism significantly influences the effectiveness in combating money laundering activities in the Maldives, while the other two factors show no significant influence. This might be due to the lack of legal power given to the FIU in Maldives in performing their task as the competent authority. There is also lack of awareness among the officers on their role and best ways in utilizing their current power as in the competent authority in Maldives' AML regime. Therefore, there is a need to revisit the legal framework especially on the powers of the FIU and to conduct frequent training to enhance their competency in detecting and preventing money laundering. Necessary measurement that can help enhance the role of the FIU should be introduced to authorities in Maldives to avoid any misuse of the financial sector for money laundering and its predicated offences.

The finding of this study would also help to understand the challenges faced by money laundering key players of the AML Regime, which will aid the policymakers on the urgent measurements needed to combat money laundering activities effectively. Practically, this study is useful in identifying 
the importance of factors in developing an effective reporting system based on a risk-based approach through customer due diligence methodologies. Future research may extend the study by covering a broader scope of money laundering regimes, such as factors influencing investigation capability, looking the role into the influence of professional skepticism of investigating officers, and investigative the support system towards money laundering investigation.

\section{ACKNOWLEDGEMENT}

The authors would like to express their gratitute to the Minister of Higher Education for HICoE research funding, Accounting Research Institute, Universiti Teknologi MARA, Malaysia for all supports and resources.

\section{REFERENCE}

Acharya, S. (2015). Role and Functions of FIU in AML/CFT Regime with Reference to Nepal. SSRN Electronic Journal.

Aurasu, A., \& Rahman, A. A. (2016). Money Laundering and Civil Forfeiture Regime: Malaysian Experience. Journal of Money Laundering Control, 19(4), 337-345.

Shanmugam, Bala, Nair, M., \& Suganthi, R. (2003). Money laundering in Malaysia. Journal of Money Laundering Control, 6(4), 373-378.

Banik, S., Kibria, B. M. G., \& Sharma, D. (2012). Testing the population coefficient of variation. Journal of Modern Applied Statistical Methods, $11(2), 325-335$.

BBC News. (2019, November). Abdulla Yameen: Maldives ex-leader convicted of money laundering. $B B C$.

Beqiri, V., \& Beqiri, N. (2018). Negative effects on the domestic economy caused by money. International Journal, 27, 87-91. 
Bullock, K., Clarke, R., \& Tilley, N. (2010). Situational Prevention of Organised Crimes (1, ed.). Willan Publishing.

Chaikin, D. (2009). How effective are suspicious transaction reporting systems? Journal of Money Laundering Control, 12(3), 238-253.

Clarke, R. V. (2009). Situational crime prevention: Theoretical background and current practice. Handbook on Crime and Deviance (pp. 259-276). Springer, New York, NY.

Dhillon, G., Ahmad, R., Rahman, A., \& Miin, N. Y. (2013). The viability of enforcement mechanisms under money laundering and anti-terrorism offences in Malaysia: An overview. Journal of Money Laundering Control, 16(2), 171-192.

FIU. (2018). FIU Maldives Annual Report 2018.

Fleming, M. H. (2005). UK Law Enforcement Agency use and management of suspicious activity reports: Towards determining the value of the regime. London: Jill Dando Institute of Crime Science, University College London.

Gara, M., Manaresi, F., Marchetti, D. J., \& Marinucci, M. (2019). The impact of anti-money laundering oversight on banks' suspicious transaction reporting: Evidence from Italy. In Questioni di Economia e Finanza (Occasional Papers) (Vol. 22).

Gilmour, N. (2016). Preventing money laundering: A test of situational crime prevention theory. Journal of Money Laundering Control, 19(4), 376-396.

IMF. (2012). Maldives: Detailed Assessment Report on Anti-Money Laundering and Combating the Financing of Terrorism. 12/01.

Junayd Mohamed. (2019). Maldives ex-president sentenced to five years for money laundering. AlJazeera News. 
Keesoony, S. (2016). International anti-money laundering laws: The problems with enforcement. Journal of Money Laundering Control, 19(2), 130-147.

Klimova, S. (2016). Role of intelligent systems in upgrading of information exchange between FSFM. Procedia Computer Science, 88, 534-537.

Leedy, P., \& Ormrod, J. (2001). Practical Research: Planning and Design (7th ed.). Upper Saddle River, NJ and Thousand Oaks, CA: Merrill Prentice Hall and SAGE Publications.

Lucian, R. D. (2010). The concept of money laundering in global economy. International Journal of Trade, Economics and Finance, 1(4), 354-360.

Maldives Independent. (2018, December 19). Maldives' biggest corruption scandal exceeded U\$90m. Retrieved September 12, 2021, from Maldivesindependent.com website: https://maldivesindependent.com/ crime-2/maldives-biggest-corruption-scandal-exceeded-u90m-143227

Maldives Monetary Authority Website (2020). Retrieved from http://www. mma.gov.mv/\#/fiu

Menz, M. (2019). Beyond placement, layering and integration-the perception of trade-based money laundering risk in UK financial services. Journal of Money Laundering Control, 22(4), 614-625.

Moamil. (2014). Money Laundering and Its Global Modes. A Serious Challenge to Law Enforcement Agencies. Some Observations. International Journal of Humanities and Social Science Invention, $3(12), 40-44$.

Mohammad, \& AlRashdan. (2012). An analytical study of the financial intelligence units' enforcement mechanisms. Journal of Money Laundering Control, 15(4), 483-495.

Mugarura, N. (2016). Uncoupling the relationship between corruption and money laundering crimes. Journal of Financial Regulation and Compliance, 24(1), 74-89. 
Muhammaddun Mohamed, Z., \& Ahmad, K. (2012). Investigation and prosecution of money laundering cases in Malaysia. Journal of Money Laundering Control, 15(4), 421-429.

Omar, N., Johari, Z. A., \& Arshad, R. (2014). Money Laundering - FATF Special Recommendation VIII: A Review of Evaluation Reports. Procedia - Social and Behavioral Sciences, 145, 211-225.

Penna, M. (2017). The 'Pre-investigative' Role of Financial Intelligence Units in Recovering Assets. In Chasing Criminal Money: Challenges and Perspectives on Asset Recovery in the EU.

PMLFT Act. Prevention of Money Laundering And Financing Of Terrorism Act. (2014).

Rachagan, S., \& Kasipillai, J. (2013). Money laundering and tax crimes in an emerging economy. International Company and Commercial Law Review, 24(7), 278-289.

Rahman, A. A. (2013). The impact of reporting suspicious transactions regime on banks: Malaysian experience. Journal of Money Laundering Control, 16(2), 159-170.

Ringle, Christian M., Wende, Sven, \& Becker, Jan-Michael. (2015). SmartPLS 3. Bönningstedt: SmartPLS. Retrieved from http://www. smartpls.com

Ross, S., \& Hannan, M. (2007). Money laundering regulation and riskbased decision-making. Journal of Money Laundering Control, 10(1), 106-115.

Moorthy, N. S. (2021, February 3). Maldives: Why Yameen camp seeks Indian attention. Retrieved September 12, 2021, from ORF website: https://www.orfonline.org/expert-speak/maldives-why-yameen-campseeks-indian-attention/ 
Simwayi, M., \& Haseed, M. (2011). The role of Financial Intelligence Units in combating money laundering: A comparative analysis of Zambia, Zimbabwe and Malawi. Journal of Money Laundering Control, 15(1), $112-134$.

Smith, G., Button, M., Johnston, L., \& Frimpong, K. (2010). Studying Fraud as White Collar Crime. Palgrave Macmillan.

Shanmugam, B., \& Thanasegaran, H. (2008). Combating money laundering in Malaysia. Journal of Money Laundering Control, 11(4), 331-344.

Ueda, T. (1993). The Suspicious Transaction Reporting System and its Effective Use, 26, 17-26.

Viritha, B., Mariappan, V., \& Haq, I. U. (2015). Suspicious transaction reporting: An Indian experience. Journal of Money Laundering Control, 18(1), 2-16.

Viritha, B., Mariappan, V., \& Venkatachalapathy, V. (2015). Combating money laundering by the banks in India: Compliance and challenges. Journal of Investment Compliance, 16(4), 78-95.

Von Lampe, K. (2011). The application of the framework of situational crime prevention to "organized crime." Criminology and Criminal Justice, 11(2), 145-163. 